\title{
Abnormal Innervation of Lower Limb Epineurial Arterioles in Human Diabetes
}

\author{
N. M. Grover-Johnson', F. G. Baumann², A. M. Imparato², G. E. Kim², and P. K. Thomas ${ }^{3}$ \\ Departments of 'Pediatrics and ${ }^{2}$ Surgery, New York University Medical Center, New York, USA, and ${ }^{3}$ Department of Neurology, \\ Royal Free Hospital, London, England
}

Summary. A quantitative ultrastructural analysis was made of the terminal innervation of epineurial arterioles in the sural nerve of 6 diabetic and 6 nondiabetic patients of comparable age (mean \pm SD: 68 \pm 9 non-diabetic, $65 \pm 16$ diabetic) with end stage peripheral vascular disease. The results demonstrated specific differences, identifiable morphometrically, in the pattern of innervation of epineurial vessels of diabetics compared with non-diabetics. The differences were: 1 ) in the diabetic group the proportion of perivascular axons found less than $7 \mu \mathrm{m}$ from the nearest smooth muscle cell.was significantly less than in the non-diabetic group $(p<0.001) ; 2)$, the mean distance of the axons from their effector sites, the vascular smiooth muscle cells, was nearly twice as far in the diabetic group compared with the nondiabetic group $(p<0.05)$; and 3 ) the mean absolute number of axons less than $7 \mu \mathrm{m}$ from the arteriole in the diabetic group was significantly less than in the non-diabetic group $(p<0.01)$. These results demonstrate that the neuropathy associated with diabetes mellitus also involves the autonomic terminal innervation of some blood vessels. In addition, this neuropathy selectively affects the vasomotor nerves closer than $7 \mu \mathrm{m}$ to the media.

Key words: Diabetic vascular disease, diabetes mellitus, diabetic autonomic neuropathy, vasomotor nerves, arterioles, morphometry.

The autonomic nervous system is frequently affected in diabetes mellitus $[25,31,38]$. The cardiovascular aspects of this diabetic autonomic neuropathy are specifically evident in abnormal Valsalva responses [34], reduced beat-to-beat variation of the heart rate
[40], and postural hypotension with blunted sympathetic responses to postganglionic stimulation [22]. Some of these cardiovascular abnormalities in diabetes closely mimic the effects of surgical sympathectomy, and it has been suggested that "autosympathectomy" resulting in denervation of blood vessels might be a component of diabetic neuropathy.

Indications that such vascular denervation occurs in diabetes are the reduced catecholamine levels found in diabetic cardiovascular tissue [26] and the enhanced response of diabetics to circulating catecholamines which is characteristic of denervation hypersensitivity $[9,10,16]$. In addition, vasomotor abnormalities apparent in diabetes, such as lack of reflex vasoconstriction and hypersensitivity to catecholamines, are clinically similar to vasomotor abnormalities seen in patients with familial dysautonomia [28] who have already been shown to lack vasomotor nerves in their skin arterioles and epineurial vessels [20].

The present quantitative ultrastructural investigation was undertaken to establish whether vascular denervation is also a component of the autonomic neuropathy in diabetes mellitus.

\section{Methods}

\section{Specimens}

Sural nerve biopsies were obtained during below knee amputation performed because of non-reconstructible peripheral vascular disease in six patients aged 45 to 90 years (mean $65 \pm 16$ ) with diabetes mellitus of 8 to over 30 years duration. Similar biopsies were obtained from six non-diabetic patients of comparable age (mean $68 \pm 9$ ) who also underwent below knee amputation as a result of non-reconstructible peripheral vascular disease (see Table 1). The comparable pattern and severity of the lower limb vascular disease in both the diabetic and non-diabetic subjects were documented by angiographic studies. None of the patients 
Table 1. Clinical data for patients studied and total number of axons found per total length of media in each case

\begin{tabular}{|c|c|c|c|c|c|c|}
\hline & $\begin{array}{l}\text { Age } \\
\text { (years) }\end{array}$ & Sex & $\begin{array}{l}\text { Duration } \\
\text { of diabetes } \\
\text { (years) }\end{array}$ & $\begin{array}{l}\text { Treatment for } \\
\text { diabetes }\end{array}$ & $\begin{array}{l}\text { Total perimeter of } \\
\text { media measured }(\mu \mathrm{m})\end{array}$ & $\begin{array}{l}\text { Total number of } \\
\text { axons counted }\end{array}$ \\
\hline \multicolumn{7}{|c|}{ Non-diabetics } \\
\hline 1 & 53 & male & - & - & 2823 & 361 \\
\hline 2 & 65 & female & - & - & 1705 & 93 \\
\hline 3 & 65 & male & - & - & 3446 & 240 \\
\hline 4 & 70 & female & - & - & 2584 & 479 \\
\hline 5 & 78 & male & - & - & 1705 & 350 \\
\hline 6 & 78 & female & - & - & 2661 & 589 \\
\hline \multicolumn{7}{|c|}{ Diabetics } \\
\hline 1 & 45 & female & $>8$ & Insulin & 3560 & 147 \\
\hline 2 & 45 & female & 25 & $\begin{array}{l}\text { Oral hypo- } \\
\text { glycemics }\end{array}$ & 4490 & 256 \\
\hline 3 & 67 & female & 25 & Insulin & 4761 & 5 \\
\hline 4 & 69 & fernale & 30 & $\begin{array}{l}\text { Oral hypo- } \\
\text { glycemics }\end{array}$ & 7127 & 39 \\
\hline 5 & 74 & female & 8 & $\begin{array}{l}\text { Oral hypo- } \\
\text { glycemics }\end{array}$ & 4020 & 318 \\
\hline 6 & 90 & male & $>30$ & $\begin{array}{l}\text { Oral hypo- } \\
\text { glycemics }\end{array}$ & 2575 & 218 \\
\hline
\end{tabular}

had undergone previous surgical sympathectomy and none had any other diagnosed disease or received drugs other than antidiabetic therapy in the period immediately preceding amputation. No patient showed signs of gangrene in the area of the sural nerve. Clinical evaluation of peripheral sensory and autonomic neuropathy was complicated by the presence of peripheral vascular disease. The six control subjects in the study were considered to be non-diabetic on documentation of fasting glucose levels and/or glucose tolerance test results together with medical and family histories negative for diabetes mellitus [33].

\section{Electron Microscopy}

Each biopsy specimen was assigned a case number to ensure blind evaluation. Tissue was processed for electron microscopic examination as follows. Each piece of sural nerve tissue was dissected free immediately after lower limb amputation and was rapidly fixed by immersion in freshly prepared, cold, $3 \%(\mathrm{v} / \mathrm{v})$ glutaraldehyde in $100 \mathrm{mmol} / 1$ phosphate buffer ( $\mathrm{pH} 7.4$ ). Following initial fixation in glutaraldehyde, specimens were washed in $100 \mathrm{mmol} / \mathrm{h}$ phosphate buffer, post-fixed in $1 \%(w / v) \mathrm{OsO}_{4}$ in $100 \mathrm{mmol} / \mathrm{l}$ phosphate buffer, washed, dehydrated in graded ethanol and embedded in Epon. A thick (1 $\mu \mathrm{m})$ cross section was cut at random from each sural nerve specimen and stained by a polychrome method [32]. In each section 2-4 epineurial arterioles were present between the nerve fascicles. The innervation of the arterioles was subjected to a quantitative study as follows.

\section{Quantitation}

Thin sections of the arterioles seen were cut on an LKB Ultratome II with a diamond knife. In order to make a representative sampling of each specimen, series of thin sections were cut at 5 different levels $10 \mu \mathrm{m}$ apart in each tissue block. Thin sections were placed on formvar-coated grids, stained with uranyl acetate and lead citrate, and examined by a Siemens Elmiskop I. All coded specimens were examined and measured by the same observer.
Each different axon profile within the adventitial sheath of each epineurial blood vessel was photographed. From the electron micrographs counts were made of the total number of axon profiles present around all the epineurial vessels in each face, and the minimum distance between each axon and the nearest medial smooth muscle cell was measured. All the data taken from five different levels of each specimen block were used to determine both the number of axons around the arteriole per specimen and the mean number of axons at one micron intervals measured outwards from the outermost smooth muscle cell layer.

The length of the perimeter of the outer edge of the media in the section was measured from photomicrographs of $0.25 \mu \mathrm{m}$ sections of the block faces using a map measurer. The above nerve counts, therefore, could also have been expressed per mm of outer media circumference. Results were not expressed on a unit circumference basis, however, for the following reasons.

Quantitative evaluation of both diabetic and non-diabetic patient groups showed no correlation between the circumference of the outer border of the media of the epineurial vessels and the axon counts associated with those vessels. This lack of correlation was found to be true whether each individual set of values was examined for each patient or when all observations for diabetic and non-diabetic groups were pooled for the respective groups. This observation remained true when circumference measurements were transferred to the logarithmic scale or to a square root measure, etc. Therefore, since the present observations indicate no relationship between vessel circumference and axon numbers, the numbers of axons for the two patient groups were analyzed directly without the necessity of considering tissue area or circumference as a covariant factor. In fact, such covariant analyses were found to yield the same conclusions as those reached below.

\section{Statistical Methods}

Axon distribution within each of the patient groups was examined first, and then the distributions compared between the two groups. Probit transformation showed axon distributions to be generally consistent with the normal distribution. Therefore, parametric 


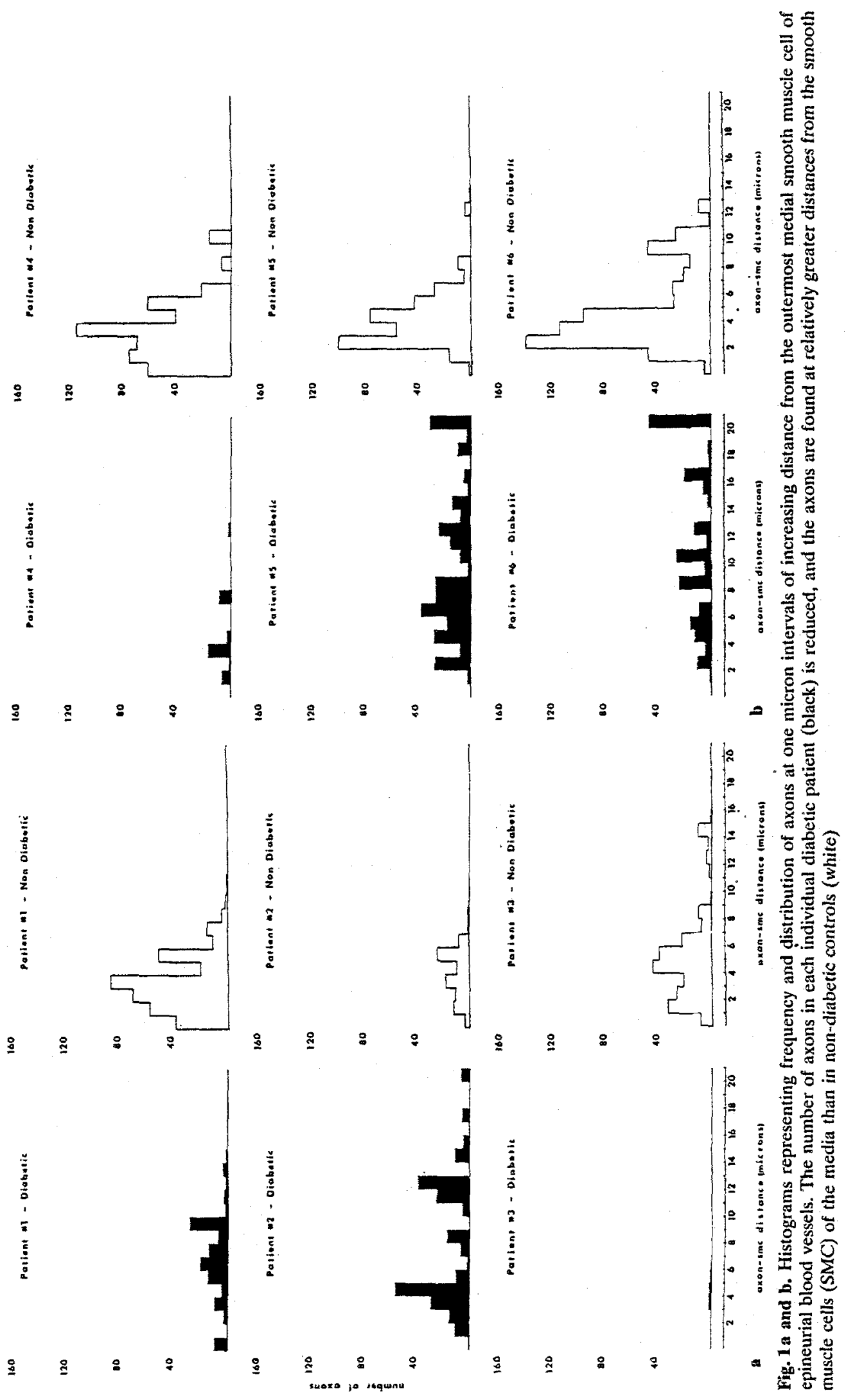




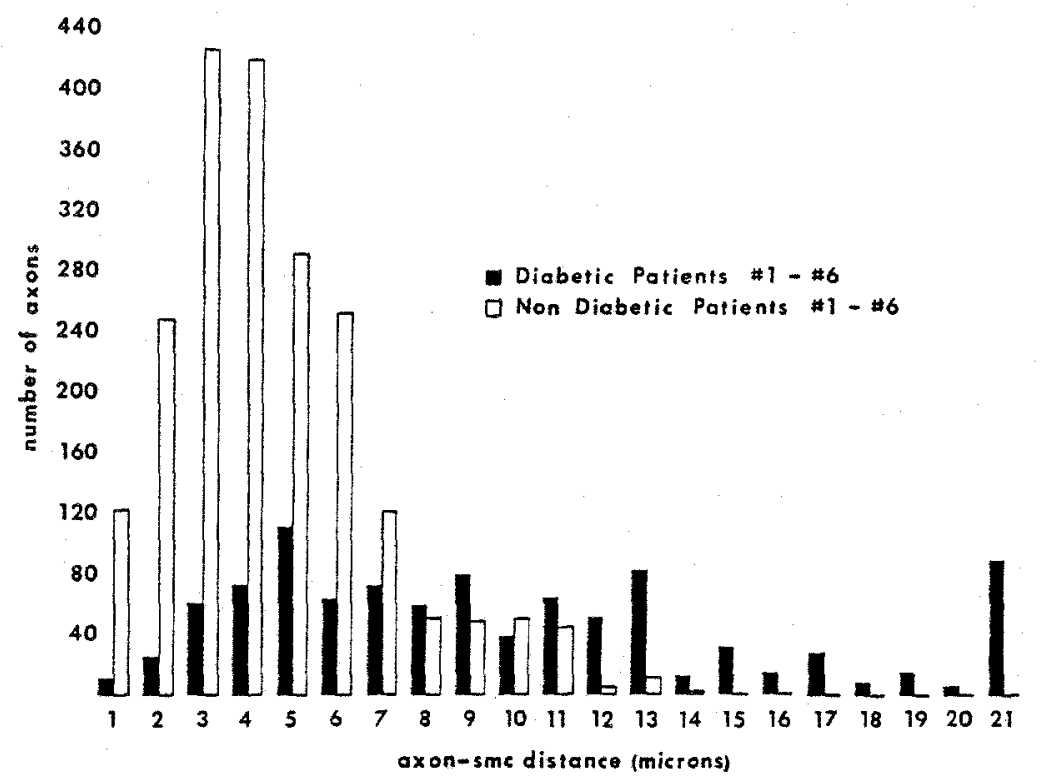

Fig. 2. Histogram compiled from all twelve cases ( 6 diabetic and 6 non-diabetic) shown in Figure $1 \mathrm{a}$ and $b$. The histogram represents the combined total frequency and distribution of axons at one micron intervals of increasing distance from the outermost medial smooth muscle cell of epineurial blood vessels. As in the individual histograms, this combined histogram exhibits pronounced skewing to the right of diabetic axon-smooth muscle cell distances

Table 2. Examination of total axon distributions of non-diabetic and diabetic groups for Poisson properties

\begin{tabular}{|c|c|c|c|c|c|c|c|c|c|}
\hline \multicolumn{5}{|c|}{ Non-diabetics } & \multicolumn{5}{|c|}{ Diabetics } \\
\hline Patient & $\begin{array}{l}\text { Average } \\
\text { distance }(\mu \mathrm{m})\end{array}$ & $\begin{array}{l}\text { No. of } \\
\text { axons }\end{array}$ & $\begin{array}{l}\text { SD } \\
\text { calculated }\end{array}$ & $\begin{array}{l}\text { SD } \\
\text { Poisson }\end{array}$ & Patient & $\begin{array}{l}\text { Average } \\
\text { distance }(\mu \mathrm{m})\end{array}$ & $\begin{array}{l}\text { No. of } \\
\text { axons }\end{array}$ & $\begin{array}{l}\mathrm{SD} \\
\text { calculated }\end{array}$ & $\begin{array}{l}\text { SD } \\
\text { Poisson }\end{array}$ \\
\hline 1 & 3.89 & 361 & 2.03 & 1.97 & 1 & 7.96 & 147 & 3.17 & 2.82 \\
\hline 2 & 4.46 & .93 & 1.82 & 2.11 & 2 & 8.57 & 256 & 4.84 & 2.93 \\
\hline 3 & 5.56 & 240 & 3.37 & 2.36 & 3 & 4.80 & 5 & 0.84 & 2.19 \\
\hline 4 & 3.95 & 479 & 2.26 & 1.99 & 4 & 5.08 & 39 & 2.78 & 2.25 \\
\hline 5 & 4.62 & 350 & 1.94 & 2.15 & 5 & 10.30 & 318 & 1.83 & 3.21 \\
\hline 6 & 5.28 & 590 & 2.86 & 2.30 & 6 & 12.49 & 218 & 6.03 & 3.53 \\
\hline
\end{tabular}

statistical methods, including the chi-square and Student's $t$ tests, were used. When heterogeneity between groups occurred it was accounted for by modifying the t-test by reducing the number of degrees of freedom by one-half. When the non-parametric MannWhitney $U$ test was applied to the same data it gave results identical to those of the parametric tests.

All results are expressed as the mean $\pm 1 \mathrm{SD}$.

\section{Results}

\section{Electron Microscopy}

The epineurial arterioles were $10-75 \mu \mathrm{m}$ in diameter and contained 1 to 8 layers of medial smooth muscle cells. Axon bundles in the adventitia of the vessels contained from 1 to 12 axonal profiles which were frequently partially devoid of a Schwann cell covering on the side of the axon closest to the media. The long axis of the axon bundles was orientated approximately in the same direction as the long axis of the vessel. Collagen fibrils and fibroblast processes were often interspersed between the axons and the nearest medial smooth muscle cells. In both non-diabetic and diabetic subjects axonal profiles contained microtubules and mitochondria. Axon varicosities demonstrated vesicles, either agranular vesicles $25-60 \mathrm{~nm}$ in diameter, granular vesicles $30-70 \mathrm{~nm}$ in diameter with a dark electron-dense core, or granular vesicles $70-150 \mathrm{~nm}$ in diameter with a less opaque core.

\section{Morphometric Results}

Axon Distribution Pattern with Distance from Arterioles (Fig. 1 and 2). Histograms representing frequency and distribution of axons at one micron intervals of increasing distance from the vessel for each of the patients are shown in Figure $1 \mathrm{a}$ and $\mathrm{b}$ and the combined data for each of the two groups in Figure 2. Histograms for the diabetic patients showed a pronounced skewing to the right, due to a relatively increased axon frequency at distances which are larger than the modal distance of the axons from the vessel. 
Table 3. Examination of near ( $\leqslant 7 \mathrm{um})$ and far $(>7 \mathrm{um})$ distributions separately for Poisson properties in non-diabetic and diabetic groups

\begin{tabular}{|c|c|c|c|c|c|c|c|c|c|}
\hline \multicolumn{5}{|c|}{$\begin{array}{l}\text { Non-diabetics } \\
\text { Axons } \leq 7 \mu \mathrm{m}\end{array}$} & \multicolumn{5}{|c|}{$\begin{array}{l}\text { Diabetics } \\
\text { Axons } \leqslant 7 \mu \mathrm{m}\end{array}$} \\
\hline Patient & $\begin{array}{l}\text { Average } \\
\text { distance }\end{array}$ & $\begin{array}{l}\text { No. of } \\
\text { axons }\end{array}$ & $\begin{array}{l}\mathrm{SD} \\
\text { calculated }\end{array}$ & $\begin{array}{l}\text { SD } \\
\text { Poisson }\end{array}$ & Patient & $\begin{array}{l}\text { Average } \\
\text { distance }\end{array}$ & $\begin{array}{l}\text { No. of } \\
\text { axons }\end{array}$ & $\begin{array}{l}\mathrm{SD} \\
\text { calculated }\end{array}$ & $\begin{array}{l}\text { SD } \\
\text { Poisson }\end{array}$ \\
\hline 1 & 3.57 & 338 & 1.65 & 1.89 & 1 & 5.02 & 64 & 2.11 & 2.24 \\
\hline 2 & 4.12 & 83 & 1.60 & 2.03 & 2 & 4.36 & 129 & 1.14 & 2.09 \\
\hline 3 & 4.36 & 200 & 1.78 & 2.09 & 3 & 4.80 & 5 & 0.84 & 2.19 \\
\hline 4 & 3.43 & 433 & 1.60 & 1.85 & 4 & 3.57 & 28 & 1.00 & 1.89 \\
\hline 5 & 4.31 & 330 & 1.41 & 2.08 & 5 & 5.18 & 127 & 1.59 & 2.28 \\
\hline 6 & 3.98 & 464 & 1.35 & 1.99 & 6 & 5.09 & 58 & 1.44 & 2.26 \\
\hline \multicolumn{5}{|c|}{ Axons $>7 \mu \mathrm{m}$} & \multicolumn{5}{|c|}{ Axons $>7 \mu \mathrm{m}$} \\
\hline Patient & $\begin{array}{l}\text { Average } \\
\text { distance }\end{array}$ & $\begin{array}{l}\text { No. of } \\
\text { axons }\end{array}$ & $\begin{array}{l}\mathrm{SD} \\
\text { calculated }\end{array}$ & $\begin{array}{l}\text { SD } \\
\text { Poisson }\end{array}$ & Patient & $\begin{array}{l}\text { Average } \\
\text { distance }\end{array}$ & $\begin{array}{l}\text { No. of } \\
\text { axons }\end{array}$ & $\begin{array}{l}\mathrm{SD} \\
\text { calculated }\end{array}$ & $\begin{array}{l}\mathrm{SD} \\
\text { Poisson }\end{array}$ \\
\hline 1 & 8.65 & 23 & 1.11 & 2.94 & 1 & 10.24 & 83 & 1.56 & 3.20 \\
\hline 2 & 7.30 & 10 & 0.67 & 2.70 & 2 & 12.84 & 127 & 3.09 & 3.58 \\
\hline 3 & 11.58 & 40 & 2.98 & 3.40 & 3 & - & - & - & - \\
\hline 4 & 8.78 & 46 & 1.85 & 2.96 & 4 & 8.91 & 11 & 2.02 & 2.98 \\
\hline 5 & 9.80 & 20 & 2.07 & 3.13 & 5 & 13.70 & 191 & 4.61 & 3.70 \\
\hline 6 & 10.10 & 126 & 1.43 & 3.18 & 6 & 15.17 & 160 & 4,66 & 3.89 \\
\hline
\end{tabular}

The histograms were statistically analyzed by means of probit transformation. The graphic probit analyses confirmed the presence of a skewed axon distribution. with increased distance from the vessel, which was to some extent present in both patient groups but much more pronounced in the diabetic group. These probit plots further suggested the presence of two separate populations of axons in each group which would account for the skewing. For both of the patient groups, the region between 6 to $9 \mu \mathrm{m}$ served to differentiate the distribution about the first mode from that about the second mode. A dividing line of $7 \mu \mathrm{m}$ was chosen as a cutoff point on the basis of these findings. The nerve-vessel distance of $7 \mu \mathrm{m}$ thus served to distinguish the axon distribution at "near" distance $(\leqslant 7 \mu \mathrm{m})$ from the axon distribution at "far" distances $(>7 \mu \mathrm{m})$.

In the non-diabetic group, $88.9 \%$ of the axons were found within the $7 \mu \mathrm{m}$ dividing line; in the diabetic group, only $41.8 \%$ of the axons are found within the $7 \mu \mathrm{m}$ dividing line $(\mathrm{p}<0.001$, chi-square test). Each individual non-diabetic case showed marked consistency in its proportional axon distribution above and below the $7 \mu \mathrm{m}$ dividing line. These six non-diabetic patients showed a range of $78.6 \%$ to $97.9 \%$ of the total number of axons distributed about the arteriole at closer than $7 \mu \mathrm{m}$ distances. The diabetic patients show more heterogeneous but nonetheless consistent findings which were in contrast to those of the non-diabetic group. The percentage of axons within the $7 \mu \mathrm{m}$ distance ranged
Table 4. Mean distance between axons and nearest smooth muscle cells in non-diabetic and diabetic groups

\begin{tabular}{llc}
\hline Patient & \multicolumn{2}{c}{ Mean nerve-muscle distance $(\mu \mathrm{m})$} \\
\cline { 2 - 3 } & Non-diabetic & Diabetic \\
\hline 1 & 3.89 & 7.96 \\
2 & 4.46 & 8.57 \\
3 & 5.56 & 4.80 \\
4 & 3.95 & 5.08 \\
5 & 4.62 & 10.30 \\
6 & 5.28 & 12.49 \\
\hline
\end{tabular}

from $26.6 \%$ to $75.0 \%$, clearly different from the range of individual values of the non-diabetic group.

Each of the distributions depicted by the histograms (Fig. 1a and b, 2), either the complete bimodal distribution or the two related unimodal distributions considered separately, showed Poisson statistical properties which imply that axon presence at any distance from an epineurial arteriole is found as a rare event (Tables 2 and 3). When the bimodal distributions were considered as two separate unimodal distributions (Table 3), another distinction could be drawn between the diabetic and non-diabetic groups. The Poisson property was evident for both near and far distributions in both groups, but the Poisson property held more closely for the far distribution of the diabetic group compared to the near distribution of axons for this group. 
Table 5. Number of axons surrounding the arterioles within and beyond $7 \mu \mathrm{m}$ in non-diabetic and diabetic groups

\begin{tabular}{|c|c|c|}
\hline \multirow[b]{2}{*}{ Patient } & \multicolumn{2}{|c|}{$\begin{array}{l}\text { No. of axons } \leqslant 7 \mu \mathrm{m} \text { from nearest smooth muscle } \\
\text { cell }\end{array}$} \\
\hline & Non-diabetic & Diabetic \\
\hline 1 & 338 & 64 \\
\hline 2 & 91 & 129 \\
\hline 3 & 200 & 5 \\
\hline 4 & 455 & 37 \\
\hline 5 & 330 & 127 \\
\hline \multirow[t]{2}{*}{6} & 464 & 58 \\
\hline & \multicolumn{2}{|c|}{$\begin{array}{l}\text { No. of axons }>7 \mu \mathrm{m} \text { from nearest smooth muscle } \\
\text { cell }\end{array}$} \\
\hline Patient & Non-diabetic & Diabetic \\
\hline 1 & 23 & 83 \\
\hline 2 & 2 & 127 \\
\hline 3 & 40 & 0 \\
\hline 4 & 24 & 2 \\
\hline 5 & 20 & 191 \\
\hline 6 & 126 & 160 \\
\hline
\end{tabular}

Distance of Axons from Arterioles (Table 4). The average distance from the media at which an axon was found for the diabetic was $8.20 \pm 2.98 \mu \mathrm{m}$ whereas that for the non-diabetic was $4.63 \pm$ $0.68 \mu \mathrm{m}$. The relative sizes of the standard deviations indicate the greater heterogeneity present among the diabetic patient group. Taking this heterogeneity into account, a Student's $t$ test of the difference between average distances is nonetheless significant $(\mathrm{p}<0.05)$.

Number of Axons Surrounding the Arteriole within and beyond $7 \mu \mathrm{m}$ (Table 5). For distances under $7 \mu \mathrm{m}$ from the arteriole, the diabetics showed an average number of axons of $70 \pm 49$; for the same range of distances, the non-diabetics showed an average number of axons of $313 \pm 146(\mathrm{p}<0.01)$. The difference between groups for axons whose distance from the vessel was greater than $7 \mu \mathrm{m}$ was not significant. The diabetic group had an average number of axons of $94 \pm 80$ in this distance range, and the non-diabetic group showed an average of $39 \pm 44$.

\section{Discussion}

The results of this study provide quantitative morphological evidence of a significantly altered spatial pattern of innervation of epineurial blood vessels in diabetic patients with end stage peripheral vascular disease compared to non-diabetic patients with clinically similar peripheral vascular disease. Although a relatively small number of patients was examined, the diabetics all demonstrated significant differences from the non-diabetics, as illustrated in Figure 1a and $b$. The altered axon distribution pattern with relation to distance from the arteriole and the increased average distance of the axons from the outer media found in the diabetic patients could well have functional significance.

The proximity of nerve terminals to vascular smooth muscle cells has been investigated previously in animal tissue, and results have shown that extremely close approximation between axons and vascular smooth muscle cells are rarely found [14, $30]$. Rather, a gap of not less than $0.2 \mu \mathrm{m}$ and often several microns in width, frequently occupied by elements of connective tissue, intervenes between the nerve terminal and the vascular smooth muscle which is its effector organ $[13,19]$.

The width of this neuromuscular gap has been shown to have important functional significance. The extent of neuronal influence on vascular smooth muscle is largely determined by the transmitter concentration at the smooth muscle cell membrane [1, 23]. At a narrow neuromuscular cleft the released transmitter has to travel over only a short distance and therefore remains concentrated, whereas in a wide cleft the transmitter becomes less concentrated due to diffusion as it travels towards the smooth muscle ceil. This increased nerve-muscle distance affects both the rate at which the transmitter reaches the effector cell and concentration at the effector cell membrane [11].

Several in vitro studies have indicated that vasomotor function, in particular the response of blood vessels to sympathetic nerve stimulation, is significantly decreased in the presence of widened distances between nerve terminals and vascular smooth muscle cells, especially if the increased nerve-muscle distance is coupled with decreased density of innervation $[1,18,23]$. Bevan has suggested that the greatest neuromuscular interval across which a biologically effective transmitter concentration is maintained is $6 \mu \mathrm{m}$ [3]. Our finding by means of a probit transformation that the region between 6 to $9 \mu \mathrm{m}$ serves to differentiate two unimodal distributions of nervesmooth muscle distances tends to substantiate this suggestion. The present study indicates that those vasomotor axons which are primarily affected in diabetes are the population nearer $(\leqslant 7 \mu \mathrm{m})$ the media and therefore those considered most important for vasomotor function.

Constrictive responses of epineurial blood vessels to stimulation by sympathetic vasomotor nerves cause alteration in blood flow [24]. The altered pattern of distribution of axonal profiles reported here 
with increased frequency of neuromuscular intervals measuring more than $7 \mu \mathrm{m}$ in diabetic epineurial blood vessels might, therefore, indicate a functional alteration in vasomotor activity, arteriolar tone, and flow in these vessels. Nevertheless, the full possible significance of the pathological changes reported here in specific relation to diabetic neuropathy and peripheral vascular disease is not known. Degenerative lesions of peripheral nerves occur frequently in diabetics [37] and are also sometimes seen in nondiabetics [12] with peripheral vascular disease. Previous morphological studies have shown that in diabetic peripheral nerves the basal lamina of the vasa nervorum are frequently extemely replicated and the vessel walls may be thickened, in some cases resulting in complete occulsion $[5,17,21,29,36,39]$. Similar pathological findings have been reported in the vasa nervorum of non-diabetics with peripheral vascular disease, but these abnormalities are less frequent and less severe $[8,15]$.

It has been postulated, however, that in diabetics partial or complete denervation of the blood vessel wall by 'autosympathectomy' might frequently occur $[27,35]$, and the present study offers morphometric evidence which supports this contention. It has further been suggested that diabetic autosympathectomy might result in the development of lesions in the vessel wall itself [6].

Experimental studies on the trophic influence of nerve on smooth muscle are as yet inconclusive, but some studies have shown that smooth muscle cell proliferation can be modified by an alteration in vessel nerve supply $[2,7]$ and that long term denervation can cause functional changes in an artery as well as structural changes [4].

The results of the present study have demonstrated specific differences, identifiable morphometrically, in the pattern of innervation of epineurial vessels of diabetics. The significantly reduced number of axons at less than $7 \mu \mathrm{m}$ in diabetics would appear to be influenced by some factor or factors which tend to make axon appearance at distances closer than $7 \mu \mathrm{m}$ rarer in the diabetic than in the non-diabetic patient. Whether this reflects a degeneration of autonomic nerves as a direct result of diabetic neuropathy or merely displacement or shrinkage of vasomotor axons from the proximity of vascular smooth muscle cells is not known. The greater degree of heterogeneity from patient to patient in the number of these near axons in diabetics may be related to other variables, such as the length of time the patients suffered from diabetes which is often very difficult to determine. In conclusion, it is possible that alterations in the innervation of blood vessels in diabetes such as have been demonstrated here might be a factor related to the predisposition of diabetic vessels to pathological alteration.

Acknowledgements. We wish to thank Dr. M. Schwartz for his statistical analyses and Deborah Goldberg for her technical assistance.

Supported in part by NHLBI Grant \# HL-20400

Note added in proof. Since the submission of this manuscript a seventh pair of cases has been analysed. This new data reveals that, in addition to the previous findings, the mean total number of axons surrounding the sural nerve arterioles is also significantly reduced in diabetics compared with non-diabetics with end-Stage lower limb peripheral arterial disease $(p \leq 0.05)$.

\section{References}

1. Bevan JA, Hosmer DW, Ljung B, Pegram BL, Su C (1974) Innervation pattern and neurogenic response of rabbit veins. Blood Vessels 11: 172-182

2. Bevan RD (1975) Effect of sympathetic denervation on smooth muscle cell proliferation in the growing rabbit ear artery. Circ Res 37: 14-19

3. Bevan JA (1978) Response of blood vessels to sympathetic nerve stimulation. Blood Vessels 15: 17-25

4. Bevan RD, Tsuru H (1979) Long-term denervation of vascular smooth muscle causes not only functional but structural change. Blood Vessels 16: 109-112

5. Bischoff A (1973) Ultrastructural pathology of peripheral nervous system in early diabetes. In: Camerini-Davalos RA, Cole HS (eds) Vascular and neurological changes in early diabetes. Academic Press, New York, p 441-449

6. Budzilovich GN (1970) Diabetic neuropathy complex. Virchows Arch [Pathol Anat] 350: 105-122

7. Campbell GR, Bibbins I, Allan I, Gamon B (1977) Effects of long term denervation on smooth muscle of the chicken expansor secundariorum. Cell Tissue Res 176: 143-156

8. Chopra IS, Hurwitz LJ (1967) Internodal length of sural nerve fibers in chronic occlusive vascular disease. I Neurol Neurosurg Psychiatry 30: 207-214

9. Christlieb AR, Munichoodappa C, Braaten JT (1974) Decreased response of plasma renin activity to orthostasis in diabetic patients with orthostatic hypotension. Diabetes 23 : $835-840$

10. Christlieb AR, Janke HU, Kraus B, Gleason RE, IcasusCabral EA, Aiello LM, Cabral BV, Solano A (1976) Vascular reactivity to angiotensin II and to norepinephrine in diabetic subjects. Diabetes 25: 268-274

11. Coimbra A, Ribeiro-Silva A, Osswald W (1974) Fine structural and autoradiographic study of the adrenergic innervation of the dog lateral saphenous vein. Blood Vessels 11: 128-144

12. Daube JR, Dyck PJ (1975) Neuropathy due to vascular diseases. In: Dyck PJ, Thomas PK, Lambert EH (eds) Peripheral neuropathy. Saunders, Philadelphia, p 714-733

13. Devine CE, Simpson FO (1967) The fine structure of vascular sympathetic neuromuscular contacts in the rat. Am J Anat 121: $153-174$

14. Dolezel S, Gerova M, Gero J, Feit J (1975) Diffusion through the vessel wall of transmitter released by sympathetic stimulation. A fluorescence and autoradiography study. Blood Vessels 12: 108-121

15. Eames RA, Lange LS (1967) Clinical and pathological study of ischaemic neuropathy. 3 Neurol Neurosurg Psychiatry 30: $215-226$ 
16. Ebaugh FG, Holt GW (1962) Polyneuropathy and diabetes mellitus. Am J Med Sci 244: 110-123

17. Fagerberg SE (1959) Diabetic neuropathy - a clinical and histological study on the significance of vascular affections. Acta Med Scand 245 [Suppl 164]: 1-97

18. Gillespie JS, Rae RM (1972) Constrictor and compliance responses of some arteries to nerve or drug stimulation. J Physiol (Lond) 223: 109-130

19. Grillo MA (1966) Electron microscopy of sympathetic tissues. Pharmacol Rev 18: 387-399

20. Grover-Johnson N, Pearson J (1976) Deficient vascular innervation in familial dysautonomia, an explanation for vasomotor instability. J Neuropathol Appl Neurobiol 2: 217-224

21. Kott I, Urca I, Sandbank Y (1974) Lumbar sympathetic ganglia in atherosclerotic patients, diabetic and non-diabetic. A comparative morphological and ultrastructural study. Arch Surg 109: 787-792

22. Leveston SA, Shah SD, Cryer PE (1979) Cholinergic stimulation of norepinephrine release in man. Evidence of a sympathetic postganglionic axonal lesion in diabetic adrenergic neuropathy. $\mathrm{J}$ Clin Invest $64: 374-380$

23. Ljung B, Bevan JA, Pegram BL, Purdy RE, Su M (1975) Vasomotor nerve control of isolated arteries and veins. Acta Physiol Scand 94: 506-516

24. Lundborg G, Branemark PI (1968) Microvascular structure and function of peripheral nerves - vital microscopic studies of the tibial nerve in the rabbit. Adv Microcirc 1: $66-68$

25. Martin MM (1953) Involvement of autonomic nerve fibres in diabetic neuropathy. Lancet I: 560-565

26. Neubauer B, Christensen NJ (1976) Norepinephrine, epinephrine and dopamine contents of the cardiovascular system in long-term diabetics. Diabetes 25: 6-10

27. Odel HM, Roth JM, Kẹting FR (1955) Autonomic neuropathy' simulating the effects of sympathectomy as a complication of diabetes mellitus. Diabetes 4: 92-98

28. Pearson F, Axelrod F, Dancis J (1974) Current concepts of dysautonomia: neuropathological defects. Ann NY Acad Sci 228: 288-300

29. Reske-Nielsen E, Lundbaek K (1968) Pathological changes in the central and peripheral nervous system of young long-term diabetics. Il Spinal cord and peripheral nerves. Diabetologia 4: $34-43$

30. Rhodin JAG (1962) Fine structure of vascular walls in mammals with special reference to smooth muscle component. Physiol Rev [Suppl] 42: 48-81

31. Rundles RW (1950) Diabetic neuropathy. Bull N Y Acad Med 26: 598-609

32. Sato $T$, Shamoto $M$ (1973) A simple rapid polychrome stain for epoxy embedded tissue. Stain Technol 48: 223-227

33. Sharp CL, Butterfield WJH, Keen H (1964) Diabetes survey in Bedford. Proc R Soc Med 57: 193-202

34. Sharpey-Schafer CP, Taylor PJ (1960) Absent circulatory reflexes in diabetic neuritis. Lancet I: 559-562

35. deTakats $G$ (1975) Sympathectomy revisited: Dodo or phoenix? Surgery 78: 644-659

36. Thomas PK (1971) The morphological basis for alterations in nerve conduction in peripheral neuropathy. Proc $R$ Soc Med 64: $295-298$

37. Thomas PK, Lascelles RG (1966) The pathology of diabetic neuropathy. Q J Med 35: 489-509

38. Thomas PK, Eliasson SG (1975) Diabetic neuropathy. In: Dyck PJ, Thomas PK, Lambert EH (eds) Peripheral neuropathy. Saunders, Philadelphia, p 956-981

39. Timperley WR, Ward JD, Preston FE, Duckworth T, O'MaIley $\mathrm{B}$ (1975) Clinical and histological Studies in diabetic neuropathy (Abstract). Proc Br Neuropathol, p 401

40. Wheeler T, Watkins PJ (1973) Cardiac denervation in diabetes. $\mathrm{Br}$ Med J IV: $584-586$

Received: November 2, 1979,

and in revised form: August 26, 1980

Dr. N. Grover-Johnson

Department of Pediatrics

NYU Medical Center

550 First Avenue

New York, NY 10016

USA 